\title{
Deaths Attributable to High Body Mass in Brazil
}

\author{
Fabiana M. Rabacow, PhD ${ }^{1,2}$; Catarina M. Azeredo, PhD³; Leandro F.M. Rezende, PhD ${ }^{4}$
}

\begin{abstract}
Accessible Version: www.cdc.gov/pcd/issues/2019/19_0143.htm
Suggested citation for this article: Rabacow FM, Azeredo CM, Rezende LF. Deaths Attributable to High Body Mass in Brazil. Prev Chronic Dis 2019;16:190143. DOI: https://doi.org/10.5888/ pcd16.190143.
\end{abstract}

\section{PEER REVIEWED}

\section{Summary}

What is already known about this topic?

High body mass index (BMI) is among the major modifiable factors to prevent noncommunicable diseases (NCDs).

What is added by this report?

We estimated the proportion of deaths from major NCDs that can be prevented in Brazil by reducing population-wide BMI.

What are the implications for public health practice?

We found that reductions in population-wide BMI might prevent up to $25.3 \%$ of major NCD deaths and $14.9 \%$ of all deaths in Brazil. Our findings can help guide public health interventions and policies to prevent NCDs in Brazil.

\section{Abstract}

Our study estimated the proportion of deaths from major noncommunicable diseases (NCDs) that could be prevented in Brazil by reducing population-wide body mass index (BMI) to different counterfactual (optimally theoretical) scenarios. We calculated population-attributable fractions by using BMI data from a representative national survey and relative risks from a published metaanalysis. Reductions in population-wide BMI could prevent 30,715 to 168,431 deaths from NCDs per year in Brazil. Cardiovascular diseases were the most preventable causes of death (5.8\%-31.5\% deaths prevented). Policies are needed to reduce population-wide BMI in Brazil.

\section{Objective}

The objective of this study was to estimate preventable deaths from major noncommunicable diseases (NCDs) in Brazil by reducing the population-wide body mass index (BMI) $\left(26.6 \mathrm{~kg} / \mathrm{m}^{2}\right)(1)$ to the following counterfactual scenarios: 1) theoretical minimum risk exposure level, where adults have a BMI of $22.0 \mathrm{~kg} / \mathrm{m}^{2}$; 2) reduction in $1.0 \mathrm{~kg} / \mathrm{m}^{2}$ at population level; and 3) reduction of BMI to levels observed in the Brazilian population in 2002 and 2003 $\left(24.6 \mathrm{~kg} / \mathrm{m}^{2}\right)$ to show the effect of the continuous increase in BMI over time (2).

\section{Methods}

We obtained BMI data from the National Health Survey, Pesquisa Nacional de Saúde (PNS), conducted in 2013 (2). PNS is the most recent survey using a representative sample of Brazilian adults. Participants were randomly selected in 3 stages: census tracts (primary sample units), households (secondary sample units), and household members aged 18 years or older (tertiary sample units). A total of 62,202 adults were interviewed in the final sample. Both body weight (in $\mathrm{kg}$ ) and height (in $\mathrm{cm}$ ) were objectively measured (3). We estimated BMI distribution (mean and standard deviation [SD], prevalence, and 95\% confidence intervals [CIs] of overweight $\left[25.0-29.9 \mathrm{~kg} / \mathrm{m}^{2}\right]$ and obesity $\left.\left[\geq 30 \mathrm{~kg} / \mathrm{m}^{2}\right]\right)$ by sex.

We obtained relative risk (RR) estimates and 95\% CIs from the Global BMI Mortality Collaboration meta-analyses (4). RRs were estimated from never-smokers who had no preexisting chronic diseases and excluded the first 5 years of follow-up to reduce confounding and reverse causality (4). We retrieved RR estimates per 5 units of BMI for all-cause, cardiovascular disease, respiratory disease, and cancer mortality.

We retrieved number of deaths from cardiovascular disease (International Classification of Diseases, Tenth Revision [ICD-10] codes I00-I99 and R96) (5), respiratory disease (ICD-10 codes J00-J99), and cancer (ICD-10 codes C00-C97 and D00-D48) in Brazil in 2013 by sex and age group from the Brazilian Information System for Mortality (6).

We calculated population attributable fractions (PAF) by sex by using the following equation (7):

$$
\mathrm{PAF}=\frac{\int R R(x) P(x) d x-\int R R(x) P *(x) d x}{\int R R(x) P(x) d x}
$$


Where $P(x)$ is the population distribution of BMI (mean and SD), $P^{*}(x)$ is the counterfactual distribution of BMI, $R R(x)$ is the relative risk of NCD associated with BMI (per $1.0 \mathrm{~kg} / \mathrm{m}^{2}$ increment), and $d x$ indicates that the integration occurred with respect to the BMI level. We used a log-logit function to represent each RR value across BMI units (8). We performed data analysis in Stata version 15.0 (StataCorp, LLC).

\section{Results}

Overall mean BMI in Brazil increased from $24.6 \mathrm{~kg} / \mathrm{m}^{2}$ in 2002 and 2003 to $26.6 \mathrm{~kg} / \mathrm{m}^{2}$ in 2013. The mean BMI was $27.0 \mathrm{~kg} / \mathrm{m}^{2}$ $\left(\mathrm{SD}, 5.5 \mathrm{~kg} / \mathrm{m}^{2}\right)$ in women and $26.2 \mathrm{~kg} / \mathrm{m}^{2}\left(\mathrm{SD}, 4.5 \mathrm{~kg} / \mathrm{m}^{2}\right)$ in men. Approximately $25 \%$ of women were obese, and $35 \%$ were overweight. The prevalence of obesity in men was $17 \%$, and $40 \%$ were overweight.

We estimated that reducing population-wide BMI to a theoretical minimum risk exposure level $\left(22.0 \mathrm{~kg} / \mathrm{m}^{2}\right)$ could prevent approximately 168,431 deaths per year in Brazil. These deaths represented about $25.3 \%$ of major NCD deaths and $14.9 \%$ of all deaths that occurred in 2013. Most of these preventable deaths were from cardiovascular disease $(106,307)$, followed by respiratory disease $(33,471)$ and cancer $(28,653)$ (Table).

Reducing population-wide BMI in Brazil to levels observed during 2002 and $2003\left(24.6 \mathrm{~kg} / \mathrm{m}^{2}\right)$ could prevent 65,721 deaths, representing $10.0 \%$ of deaths from major NCDs and $5.8 \%$ of all deaths. A reduction in $1.0 \mathrm{~kg} / \mathrm{m}^{2}$ of population-wide BMI could prevent 30,715 deaths, representing $4.6 \%$ of deaths from major NCD and $2.7 \%$ of all deaths (Table).

\section{Discussion}

Approximately $25.3 \%$ of major NCD deaths and $14.9 \%$ of all deaths could be prevented each year in Brazil by reducing population-wide BMI. Other scenarios indicated that $4.6 \%$ of major NCD deaths could be avoided by reducing $1.0 \mathrm{~kg} / \mathrm{m}^{2}$ of BMI and $10 \%$ of NCD deaths by reducing BMI to levels observed during 2002 and 2003.

The reduction of BMI would have the greatest effect on cardiovascular disease deaths, which account for one-third of all deaths in Brazil (9). The World Health Organization Global Plan for 2025 involves a series of targets to reduce $25 \%$ of premature mortality from major NCDs (10), among which is halting the rise in obesity rates. Our study considered more ambitious scenarios of BMI reduction, which can be a challenge. Obesity increase is primarily driven by obesogenic environments. To reverse this trend, some in the scientific community, especially in the fields of nutrition and physical activity, have suggested modifying obesogenic environments through fiscal and regulatory actions (eg, taxation, labeling, marketing of ultraprocessed products) (11).

Our study has limitations. Although BMI is a useful indicator of body fat, it does not differentiate between lean and adipose tissues (12). Furthermore, we used RR estimates from a meta-analysis that included data from 4 continents but not Brazil (4). These RR estimates were not stratified by potential effect modifiers (eg, sex, age). Whether these RR estimates are applicable to Brazilians is unknown. On the other hand, by using RR estimates for neversmokers who had no preexisting chronic diseases and excluding the first 5 years of follow-up, we reduced reverse causation bias and achieved more reliable estimates of deaths attributable to BMI (4).

By reducing population-wide BMI in Brazil, 30,715 to 168,431 deaths per year from NCDs could be prevented. Policies aimed to reduce obesogenic environments are needed to decrease population-wide BMI in Brazil.

\section{Acknowledgments}

This study did not receive any external funding. No copyrighted material, surveys, instruments, or tools were used to produce this article.

\section{Author Information}

Corresponding Author: Fabiana Maluf Rabacow, PhD, Universidade Católica Dom Bosco, Desenvolvimento Local, Avenida Tamandaré, 6000 Campo Grande Mato Grosso do Sul 79117-010, BR. Telephone: (55) 67 98-16-55-092. Email: fabirabacow@hotmail.com.

Author Affiliations: ${ }^{1}$ Universidade Católica Dom Bosco, Desenvolvimento Local, Avenida Tamandaré, 6000, Campo Grande, Mato Grosso do Sul, Brazil. ${ }^{2}$ Universidade Anhanguera Uniderp, Campo Grande, Brazil. ${ }^{3}$ Curso de Nutrição, Faculdade de Medicina, Universidade Federal de Uberlândia, Minas Gerais, Brazil. ${ }^{4}$ Universidade Federal de São Paulo, Escola Paulista de Medicina, Departamento de Medicina Preventiva, São Paulo, Brazil.

\section{References}

1. Brazilian Institute of Geography and Statistics. Pesquisa Nacional de Saúde 2013. Percepção do estado de saúde, estilo de vida e doenças crônicas. Brasil, Grandes Regiões e

\footnotetext{
The opinions expressed by authors contributing to this journal do not necessarily reflect the opinions of the U.S. Department of Health and Human Services, the Public Health Service, the Centers for Disease Control and Prevention, or the authors' affiliated institutions.
} 
Unidades da Federação. In: Estatística, IBGE, ed. Rio de Janeiro (BR); 2013.

2. Brazilian Institute of Geography and Statistics. Pesquisa de Orçamentos Familiares 2002-2003: Análise da disponibilidade domiciliar de alimentos e do Estado Nutricional no Brasil. In: Estatística, IBGE, ed. Rio de Janeiro (BR); 2004.

3. Szwarcwald CL, Malta DC, Pereira CA, Vieira ML, Conde WL, Souza Júnior PR, et al. Pesquisa Nacional de Saúde no Brasil: concepção e metodologia de aplicação. Cien Saude Colet 2014;19(2):333-42.

4. Di Angelantonio E, Bhupathiraju SN, Wormser D, Gao P, Kaptoge S, Berrington de Gonzalez A, et al.; Global BMI Mortality Collaboration. Body-mass index and all-cause mortality: individual-participant-data meta-analysis of 239 prospective studies in four continents. Lancet 2016; 388(10046):776-86.

5. World Health Organization. International statistical classification of diseases and related health problems. 10th revision, edition 2010. Geneva $(\mathrm{CH})$ : World Health Organization Press; 2011.

6. Departamento de Informática do Sistema Único de Saúde. Sistema de Informação sobre mortalidade, 2013. Brasil Ministério da Saúde. Brasília: http://www.datasus.gov.br. Accessed September 11, 2019.

7. Murray CJ, Ezzati M, Lopez AD, Rodgers A, Vander Hoorn S. Comparative quantification of health risks conceptual framework and methodological issues. Popul Health Metr 2003;1(1):1.

8. Arnold M, Pandeya N, Byrnes G, Renehan PAG, Stevens GA, Ezzati PM, et al. Global burden of cancer attributable to high body-mass index in 2012: a population-based study. Lancet Oncol 2015;16(1):36-46.

9. Malta DC, França E, Abreu DMX, Perillo RD, Salmen MC, Teixeira RA, et al. Mortality due to noncommunicable diseases in Brazil, 1990 to 2015, according to estimates from the Global Burden of Disease study. Sao Paulo Med J 2017; 135(3):213-21.

10. World Health Organization. Global status report on noncommunicable diseases. Geneva $(\mathrm{CH})$ : World Health Organization Press; 2013.

11. Swinburn BA, Sacks G, Hall KD, McPherson K, Finegood DT, Moodie ML, et al. The global obesity pandemic: shaped by global drivers and local environments. Lancet 2011; 378(9793):804-14.

12. Meeuwsen S, Horgan GW, Elia M. The relationship between BMI and percent body fat, measured by bioelectrical impedance, in a large adult sample is curvilinear and influenced by age and sex. Clin Nutr 2010;29(5):560-6.

The opinions expressed by authors contributing to this journal do not necessarily reflect the opinions of the U.S. Department of Health and Human Services, the Public Health Service, the Centers for Disease Control and Prevention, or the authors' affiliated institutions. 


\section{Table}

Table. Numbers of Deaths Preventable by Reductions in BMI, by Sex, Counterfactual Scenario, and Causes of Death in Brazil ${ }^{\mathrm{a}}$

\begin{tabular}{|c|c|c|c|c|c|c|c|}
\hline \multirow[b]{2}{*}{ Outcomes } & \multirow[b]{2}{*}{ Total No. of Deaths } & \multicolumn{2}{|c|}{$\begin{array}{c}\text { Theoretical Minimum Risk } \\
\text { Exposure Level }^{b}\end{array}$} & \multicolumn{2}{|c|}{$\begin{array}{l}\text { Reduction in } 1.0 \mathrm{~kg} / \mathrm{m}^{2} \text { at } \\
\text { Population Level }\end{array}$} & \multicolumn{2}{|c|}{ BMI Levels in $2002-2003^{d}$} \\
\hline & & PAF, \% & $\begin{array}{l}\text { No. of Preventable } \\
\text { Deaths }\end{array}$ & PAF, \% & $\begin{array}{l}\text { No. of Preventable } \\
\text { Deaths }\end{array}$ & PAF, $\%$ & $\begin{array}{l}\text { No. of Preventable } \\
\text { Deaths }\end{array}$ \\
\hline \multicolumn{8}{|l|}{ Cancer } \\
\hline Both & 193,936 & 14.8 & 28,653 & 2.5 & 4,933 & 5.3 & 10,366 \\
\hline Men & 103,459 & 13.3 & 13,764 & 2.6 & 2,684 & 4.7 & 4,850 \\
\hline Women & 90,477 & 16.5 & 14,890 & 2.5 & 2,249 & 6.1 & 5,515 \\
\hline \multicolumn{8}{|c|}{ Cardiovascular disease } \\
\hline Both & 337,559 & 31.5 & 106,307 & 5.8 & 19,529 & 12.4 & 41,979 \\
\hline Men & 176,744 & 28.9 & 51,014 & 5.9 & 10,438 & 11.0 & 19,514 \\
\hline Women & 160,815 & 34.4 & 55,293 & 5.7 & 9,091 & 14.0 & 22,465 \\
\hline \multicolumn{8}{|c|}{ Respiratory disease } \\
\hline Both & 133,124 & 25.1 & 33,471 & 4.7 & 6,253 & 10.0 & 13,376 \\
\hline Men & 69,143 & 22.7 & 15,690 & 4.8 & 3,319 & 8.8 & 6,100 \\
\hline Women & 63,981 & 27.8 & 17,781 & 4.6 & 2,934 & 11.4 & 7,276 \\
\hline \multicolumn{8}{|c|}{ Major NCD deaths ${ }^{e}$} \\
\hline Both & 664,619 & 25.3 & 168,431 & 4.6 & 30,715 & 9.9 & 65,721 \\
\hline Men & 349,346 & 23.0 & 80,468 & 4.7 & 16,441 & 8.7 & 30,464 \\
\hline Women & 315,273 & 27.9 & 87,963 & 4.5 & 14,274 & 11.2 & 35,257 \\
\hline \multicolumn{8}{|c|}{ All-cause mortality } \\
\hline Both & $1,130,624$ & 14.9 & 168,431 & 2.7 & 30,715 & 5.8 & 65,721 \\
\hline Men & 635,751 & 12.7 & 80,468 & 2.6 & 16,441 & 4.8 & 30,464 \\
\hline Women & 494,873 & 17.8 & 87,963 & 2.9 & 14,274 & 7.1 & 35,257 \\
\hline
\end{tabular}

Abbreviations: BMI, body mass index; NCD, noncommunicable disease; PAF, population attributable fraction; SD, standard deviation.

${ }^{a}$ Data sources: Brazilian Institute of Geography and Statistics (1), Brazilian Institute of Geography and Statistics (2), Di Angelantonio et al (4), Departamento de Informática do Sistema Único de Saúde (6).

${ }^{\mathrm{b}}$ Theoretical minimum risk exposure level was $22.0 \mathrm{~kg} / \mathrm{m}^{2}\left(\mathrm{SD}, 1.0 \mathrm{~kg} / \mathrm{m}^{2}\right)$ for both sexes.

${ }^{\mathrm{c}}$ Reduction in $1.0 \mathrm{~kg} / \mathrm{m}^{2}$ at population level was $25.6 \mathrm{~kg} / \mathrm{m}^{2}\left(\mathrm{SD}, 5.1 \mathrm{~kg} / \mathrm{m}^{2}\right)$ for both sexes, $25.2 \mathrm{~kg} / \mathrm{m}^{2}\left(\mathrm{SD}, 4.5 \mathrm{~kg} / \mathrm{m}^{2}\right)$ for men, and $26.0 \mathrm{~kg} / \mathrm{m}^{2}(\mathrm{SD}, 5.5 \mathrm{~kg} /$ $\mathrm{m}^{2}$ ) for women.

${ }^{d}$ BMl levels in 2002 and 2003 were $24.6 \mathrm{~kg} / \mathrm{m}^{2}\left(\mathrm{SD}, 4.3 \mathrm{~kg} / \mathrm{m}^{2}\right.$ ) for both sexes, $24.5 \mathrm{~kg} / \mathrm{m}^{2}$ (SD, $\left.3.8 \mathrm{~kg} / \mathrm{m}^{2}\right)$ for men, and $24.6 \mathrm{~kg} / \mathrm{m}^{2}\left(\mathrm{SD}, 4.8 \mathrm{~kg} / \mathrm{m}^{2}\right)$ for women.

${ }^{\mathrm{e}}$ Cardiovascular disease, cancer, and respiratory disease mortality.

The opinions expressed by authors contributing to this journal do not necessarily reflect the opinions of the U.S. Department of Health and Human Services, the Public Health Service, the Centers for Disease Control and Prevention, or the authors' affiliated institutions. 